National Agriculture and Water Research Center, Ministry of Agriculture and Water, Saudi Arabia.

\title{
THE ROLE OF SMALL RUMINANTS IN THE EPIZOOTIOLOGY OF FOOT AND MOUTH DISEASE IN SAUDI ARABIA WITH REFERENCE TO THE ECONOMIC IMPACT OF THE DISEASE ON SHEEP AND GOATS
}

(With 4 Tables and 5 Figures)

\section{By \\ M. A. FARAG; A. AL-SUKAYRAN*, K.S. MAZLOUM \\ *: Department of Foot and Mouth Disease, Veterinary Serum and Vaccine and A.M.AL-BOKMY \\ Research Institute, Abbassia, Cairo - Egypt. \\ (Received at 16/9/1998)}

دورالمجترات الصغيرة فى وبائية مرض العمى القلاعية فى المطكة العربية

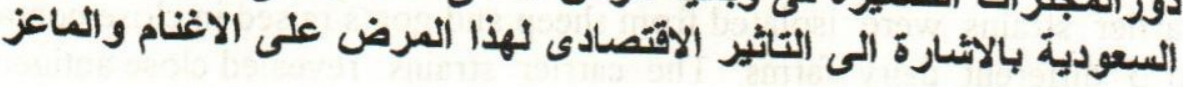

مختار عامر فرج ، عبدالله محمد الصقيران ، كمال صابر مظلوم

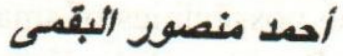

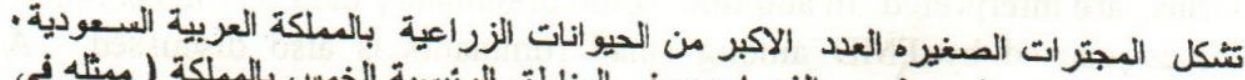

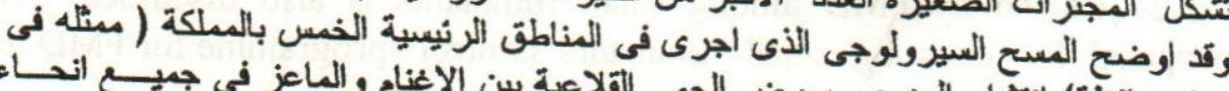

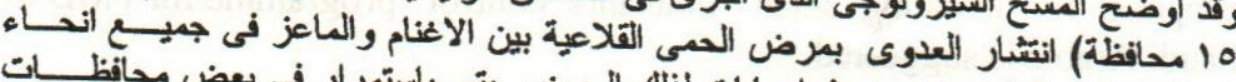

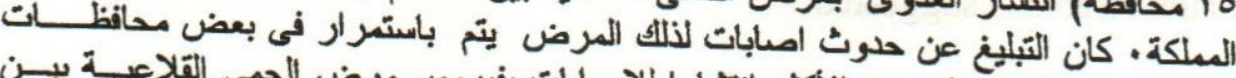

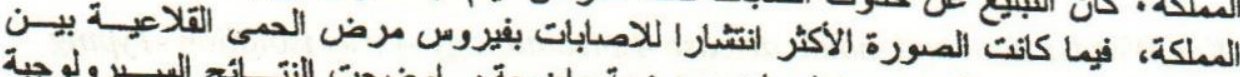

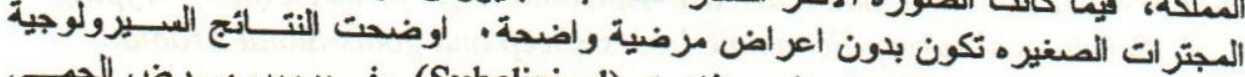

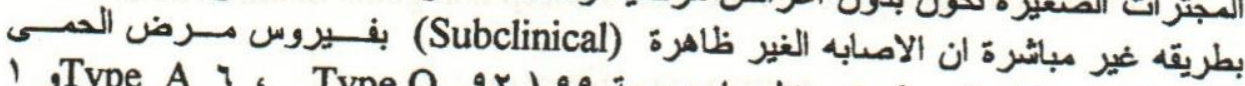

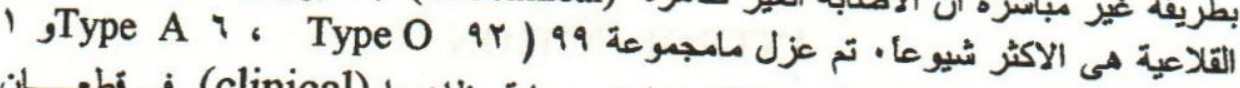
(Type Asia1

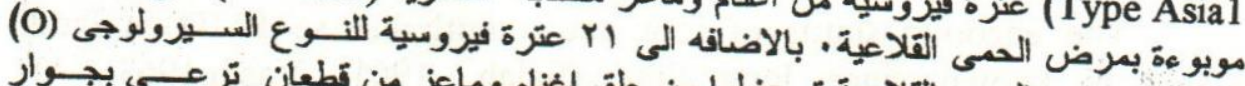

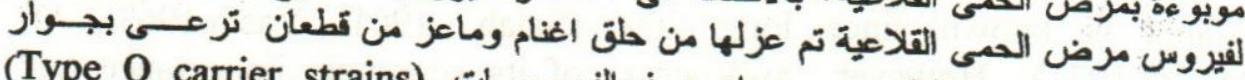

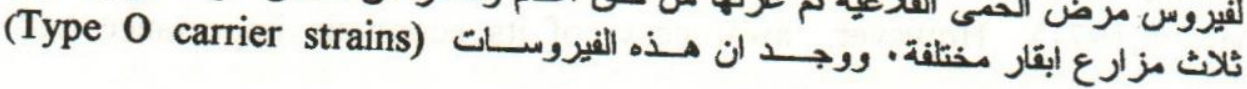




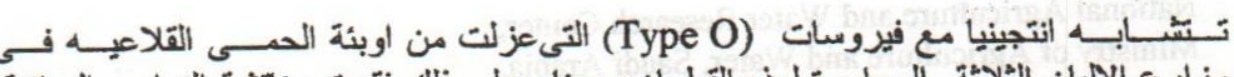

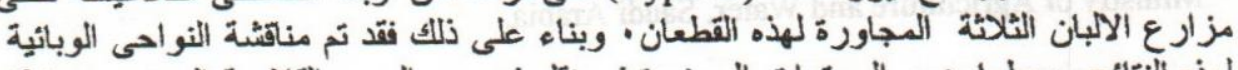

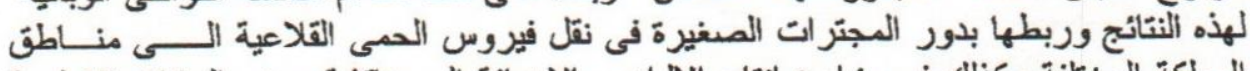

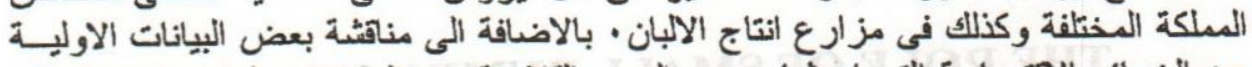

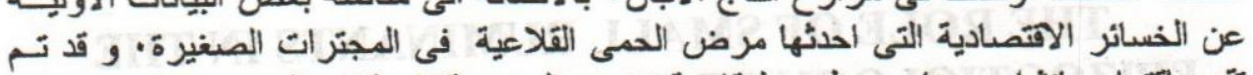

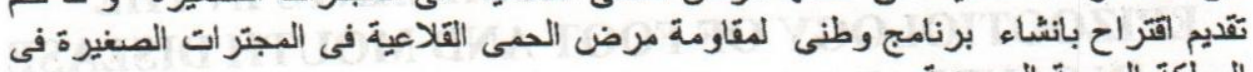
المملكة العزبية السعودية.

\section{SUMMARY}

Small ruminants represent the main population of domestic animals in Saudi Arabia. Serological surveys carried out in the main 5 Regions of the Kingdom (represent 15 Saudi provinces) revealed that infection with Foot and Mouth Disease (FMD) virus is nation-wide among sheep and goats. Clinical FMD in small ruminants is not common and the disease was currently reported in some provinces of the Kingdom. However, serological findings indirectly indicate that subclinical infection with FMD virus is more common. A total of 99 FMD viruses (92 type 0,6 type A and one type Asia 1) were isolated from clinically affected sheep and goats in herds exposed to FMD outbreaks. 21 serotype O FMD virus carrier strains were isolated from sheep and goats raised in close contact to 3 different dairy farms. The carrier strains revealed close antigenic relationship to the type $\mathrm{O}$ viruses that caused outbreaks in the neighbouring dairy farms. The epizootiological aspects of the obtained results in correlation to the possibilities of small ruminants in transmitting FMD virus to the different Regions of the Kingdom as well as to the dairy farms are interpreted. In addition, some preliminary data on the economic losses caused by FMD among small ruminants is also discussed. A proposal for initiating small ruminants control programme for FMD in Saudi Arabia is suggested.

Key Words: Foot and mouth disease -Epizootiology -Virus isolation -Typing Serological survey-Economic losses-sheep and goats-Saudi Arabia.

\section{INTRODUCTION}

The enzootic status of foot and mouth disease (FMD) in Saudi Arabia is known since long time (Salah, 1961., Yasin, 1963., AlMezini,1971). However, awareness of its economic importance had 
increased only recently after the occurrence of the disease in modern dairy farms applying relevant preventive measures (Hafez, 1987). On the other hand, epizootiological information on the disease among indigenous animals and animals imported for slaughter, which are mostly small ruminants, was vague. The numbers of native sheep and goats in Saudi Arabia reportally are 7,321,172 and 4,308,509, respectively (Anon 1996). Most of these animals are nomadic and moving from region to region as well as the free range animals from the neighbouring countries. Moreover, about 6 to 7 million small ruminats are annualy imported for slaughter. Approximately, half of the imported sheep and most of the imported goats are originating from countries where FMD is enzootic (Hafez et al., 1994).

FMD control programmes in Saudi Arabia are mainly applied in dairy farms while most of the indigenous small ruminants are not vaccinated (Hafez et al., $1993 \mathrm{a}$ and b). On the other hand, clinical FMD was observed among sheep and/or goats in some Provinces. Eight large breeding farms, 23 nomadic flocks and 15 small breeding herds located in the Northern, Eastern and Central Regions of the Kingdom were affected (Unpublished data). Before this study, samples collected from small ruminants were submitted to the FMD-World Reference Laboratory (FMD-WRL), Pirbright,U.K., for diagnosis.

Thereafter, local studies on FMD were initiated and it became possible to carry out long term investigations on the epizootiological aspects of the disease under the Saudi field conditions. Data obtained from the field Veterinarians of 23 Provinces revealed the suspicion of clinical FMD among sheep and goats in $8(35 \%)$ and $2(9 \%)$ provinces, respectively (Hafez et al., 1993 b). However, out of a total of 2,897 sheep and goats imported for slaughter from Sudan, Somalia, Egypt, Turkey, Syria, Jordan, Yemen and Pakistan, 117 (4\%) were positive for the detection of VIA antibodies (Hafez et al., 1994).

In the present studies, virological, serological and epizootiological data on the clinical and subclinical infection of sheep and goats in Saudi Arabia with FMD virus are interpreted. This data highlights the possible role of these animals on the transmission and persistence of the disease in the Kingdom. In addition, some preliminary data on the economic losses caused by FMD among small ruminants is also discussed. A proposal for inititating a control programme for FMD among small ruminants in Saudi Arabia is suggested. 


\section{MATERIAL and METHODS}

\section{Field samples}

A total of 150 samples (epithelial tissues, heart, lymph nodes, whole dead lambs or kids) were collected from the following groups of sheep and/or goats for virus isolation:

1- Clinically affected nomadic sheep and/or goats.

2- Suddenly dead lambs and/or kids in nomadic flocks.

3- Large and small sheep breeding farms with suspected outbreaks of FMD.

\section{Probang samples}

Probang samples were collected from 14,8 and 10 sheep, and 19,10 and 10 goats, raised in 3 herds located in Al-Kharj, Tebrak and Mezahmiyiah Provinces respectively. Sample collection was carried out using probang cups as described by Hedger and Stubbing (1971), the samples were treated with equal amount of trichlorotrifluoro-ethan as described by Sutmoller \& Cottral (1967).

Virus isolation and typing

Primary isolation of FMD virus (from field \& probang samples) was made in primary tissue-culture monolayers of bovine kidney cells as described by Hafez et al., (1993 a). An Elisa FMD-typing kit provided by the FMD World Reference Laboratory (WRL) was used. Indirect sandwich Elisa described by Roeder \& Blanc Smith (1987) with slight modification (Anon, 1989), was applied for serotyping of the isolates strains of FMD virus.

\section{Serum samples}

Blood samples were collected from 6159 non-vaccinated indigenous sheep and 1384 goats by Province Veterinarians of the main 5 Regions (represent 15 Saudi Provinces) for the detection of VIA antibodies using immunodiffusion test. These provinces are located in the Central, Eastern, Northren, Southern and Western Regions of the Kingdom.

\section{Immunodiffussion test}

The immunodiffussion test was carried out in $100 \mathrm{~mm}$ Petri dishes using FMD virus infection associated (VIA) antigen and reference positive serum as described by Hafez et al., (1994).

\section{Virus neutralization test}

The microneutralization test was applied using BHK-21 monolayers, as described elsewhere (Golding et al., 1976). One hundred 
and fifty serum samples (103 sheep and 47 goats) which showed precipitating activity against VIA antigen, and 120 sera ( 80 sheep and 40 goats) without precipitating antibodies against VIA antigen were tested. These sera originated from different provinces covering the main 5 Regions of the Kingdom. Each serum sample was tested against four serotypes of FMD virus, using the virus strains 01 Manisa 68, A22 Iraq, C3 Phillipines and Asia1 India 79, respectively.

\section{RESULTS}

\section{Epizootiological data}

In collaboration with the concerned farm Veterinarian(s), the following data were collected after the occurrence of FMD outbreaks in each herd. Outbreaks of FMD usually occurred in sheep and goats in a mild form. Some outbreaks are severe. During these outbreaks, the reported data revealed that all age-groups of the animals were affected with morbidity rates ranging from 10 to $40 \%$. Fever and anorexia are observed among some animals. Vesicle formation is not prominent. Lameness is often the only overt sign of the disease in the affected flocks. High mortalities among newborn lambs/kids (which may reach to 90 to $100 \%$ of animals younger than one month of age. (Unpublish data) are known. Also lambs/kids more than 4-6 months were lost during these outbreaks.

\section{Virus isolation and typing}

Examination of samples collected from 150 suspected FMD outbreaks/foci among sheep and goats in different Regions of the Kingdom revealed positive diagnosis in $99(66 \%)$. Serotype O of FMD virus was confirmed in 92 cases including 6 outbreaks in large breeding farms. Six serotype A were isolated from outbreaks in 2 large breeding farms and 4 foci in small breeding herds. One serotype, Asia 1 FMD virus, was also isolated from a nomadic flock. The location from which the samples were collected and then positive diagnosis was confirmed are shown in Figure 2.

\section{Virus isolation and typing from carrier animals}

Out of a total of 71 probang samples examined in cell cultures, 21 virus strains were isolated (Table 1). The samples were from otherwise apparently healthy sheep and goats of one large breeding farm and 2 small breeding herds located in Al-Kharj, Tebrak and Mezahmyiah Provinces 


\section{Assiut Vet. Med. J. Vol. 40 No. 79, October 1998.}

respectively. All the isolated carrier strains were found to be serotype $O$ of FMD virus.

\section{Serological results}

\section{Detection of precipitating antibodies against VIA antigen}

The results of immunodiffusion tests are shown in Figure 1 \& Table 2. Of 6159 sheep sera and 1384 goats sera, $1263(21 \%)$ and 232 $(17 \%)$ were positive for the presence of precipitating antibodies against VIA antigen. The goats sera from Arar, Medina and Gizan were all negative when tested for antibodies against VIA. However, a proportion of sheep sera from animals raised in the same provinces were positive (Figures 1\&3).

\section{Detection of neutralizing antibodies against FMD virus}

Examination of 150 serum samples (103 sheep and 47 goats) with precipitating antibodies against VIA antigen by virus neutralization test confirmed the presence of antibodies against one or more serotype of $\mathrm{O}$, $A$ and Asial of FMD virus in all tested samples (Table 3 \& Figure 4). The positive percentage of the tested sera against serotype $\mathrm{O}, \mathrm{A}, \mathrm{Asia} 1, \mathrm{O} \& \mathrm{~A}$ and O\&Asial in the main 5 Regions of the Kingdom are shown in Table 3 \& Figure 4. Antibodies against serotype $\mathrm{O}$, A were detected in all 5 Regions, but antibodies against type Asia1 and O\&Asial were detected in the Central Region only. Antibodies against serotypes O\&A were detected in the Northern, Central and Southern Regions (Table 3 \& Figure 4). In addition, out of 120 sera ( 80 sheep and 40 goats) without precipitating antibodies against VIA antigen re-tested by virus neutralization, various titers (ranging from 1:10 to 1:160) of neutralizing antibody against one or more serotype of FMD virus were detected. The percentages of positive results of the tested sera against serotypes $\mathrm{O}, \mathrm{A}$, Asial and $\mathrm{O} \& \mathrm{~A}$ in the 5 main Regions are shown in Table 4 \& Figure 5. However, no antibody against serotype $\mathrm{C}$ and $\mathrm{O} \&$ Asial were detected in any sera tested.

\section{DISCUSSION}

Interpretion of virological, serological and epizootiological data

The main population of domestic animals in Saudi Arabia is small ruminant. The uncontrolled movements of these animals within the country or over the international borders between the Kingdom and neighbouring countries gives sheep and goats an important role in the epizootiology of FMD in Saudi Arabia. Our epizootiological data and 


\section{Assiut Vet. Med. J. Vol. 40 No. 79, October 1998.}

seroepizootiological results revealed that the occurrence of FMD among sheep and goats was mostly subclinical (Burrows, 1968., McVICAR and Sutmoller, 1972., Andrerson et al.,1976). Lameness, pyrexia and/or anorexia was the most common clinical signs observed among some animals in the affected flocks. Sheep and goats are considered as maintaining host for infection with FMD virus (Brookby, 1981). The isolation of $99 \mathrm{FMD}$ virus strains (92 type O, 6 type A and 1 type Asia1) from sheep and goats raised in 8 provinces located in the Northern, Eastern and Central Regions of the Kingdom indicates a nation-wide prevalence of FMD virus(es). Therefore, the movements of infected small ruminants with the prevalent field FMD viruses from one area to another area plays an important role in the transmission and persistence of FMD in Saudi fields. The excreted virus from clinical FMD cases (sheep and goats) can affect susceptible or immune animals. The infection of such animals will lead to further cycles of virus excretion and amplification of the infection among animals of the flock (McVICAR \& Sutmoller, 1976., Donaldson \& Kitching, 1989). On the other hand, the excreted virus will be transmitted to susceptible cattle and the clinical disease may occur (Brooksby, 1981). Comparative molecular studies carried out in FMDWRL (Pribright, London, U.K.) revealed closer antigenic relationship of the serotype $O$ carrier strains (selected from 21 serotype $O$ carrier strains isolated from sheep and goats) to the type $O$ viruses that caused outbreaks in the neighbouring dairy herds (FMD-WRL, Kitching, P., personal communication). These results reinforce the evidence that the infected sheep and goats will be transmitting the virus to the neighbouring dairy farms. High mortality (reaching up to $90 \%$ ) among lambs or kids was observed in susceptible sheep and goats flocks affected with FMD virus (Hafez et al., 1995 b).

The detection of precipitating antibodies against VIA antigen has been considered as a significant tool for epizootiological survey of FMD in Saudi Arabia (Dawe \& Durojaive, 1986., Farag, 1983., Fernandez et al., 1975., Hafez et al., 1993 b., McVICAR \& Sutmoller, 1970.). The detection of VIA antibodies in $17 \%, 26 \%, 5 \%, 5 \%, 9 \%$ of sheep and in $9 \%, 7 \%, 23 \%, 14 \%, 4 \%$ of goats raised in the Central, Northern, Southern, Eastern and Western Regions respectively of the Kingdom indicates a nation-wide prevalence of FMD virus(es).

The serotyping of the currently isolated FMD viruses from field cases ( 99 isolates) and carrier animals (21 isolates) revealed that serotype $O$ is the predominant serotype in Saudi Arabia (92/99 of field viruses, 21 
carrier strains). $6 \%(6 / 99)$ type $\mathrm{A}$ and $1 \%(1 / 99)$ type Asial were also detected from the typed viruses. These findings are in accordance with our seroepizootiological results which indicated the detection of naturally occurring neutralizing antibodies against serotyping $\mathrm{O}$, A and Asial of FMD in the sera collected from non-vaccinated sheep and goats raised in the main 5 Regions of the Kingdom (Hafez et al., 1993 a, Woodbury et al., 1994). Despite the small number of sera examined by neutralisation tests, the results obtained confirm the present nationwide circulation of serotypes $\mathrm{O}, \mathrm{A}$ and Asial. Quadrivalent vaccine containing strains of $\mathrm{O}$, A, C and Asia 1 is used in Saudi Arabia. The failure to detect type C antibodies and the detection of such antibodies in vaccinated animals (unpublished data) is an indirect indication that the examined animals had not been vaccinated.

The high percentage of positive serological test results in sheep and goats in many Regions of Saudi Arabia, in the absence of clinical FMD among these animals, indicates the importance of these range animals in transmitting FMD virus between Regions within the country.

A high percentage of sheep and goats that have recovered from FMD can become carriers for up to 2 years (Burrows, 1968., McVICAR and Sutmoller, 1969, Cottral, 1969). Despite the continuing failure to demonstrate transmission of FMD virus from carrier to susceptible animals, there are strong indications that some outbreaks of FMD which occurred in Zimbabwe and an outbreak which occurred in a Saudi dairy farm were associated with the movement of suspected carrier animals (Salt, 1992).

\section{Economical assessements}

FMD causes very high mortality among the lambs and kids crop of many small owners (reaching in some cases up to $90 \%$, Unpublished data). The main income of most of these owners is dependent on selling the fattened yearling male animals. The deaths of the newborn animals simply deprives the owner from the next season new generation of females for replacing old ones or young males for selling. Such losses have direct influence on the socioeconomic conditions of many nomadic families, and on the national plans for development of animals resources. The estimated population of indigenous sheep and goats in Saudi Arabia are about $7,321,172$ and $4,308,509$ respectively (Anon, 1996). Usually, due to selling off of males for slaughter, it is considered that the half of this population are females and each will give an average birtof only one offspring per year. Therefore, about 5,815,000 lambs/kida may be born 


\section{Assiut Vet. Med. J. Vol. 40 No. 79, October 1998.}

annually in Saudi Arabia. If the mortality rate of the newly born animals reached $15 \%$ (in the absence of any vaccination history), about 872,250 lambs/kids may annually die due to infection with FMD virus. The estimated price of the newborn lambs/kids and the additional losses related to its death would be about 150 Saudi Riyal (SR) per (dead) lamb/kid (A.AL-Mukayel and A.M.AL-Bokmy, personal communication). Therefore, the total annual losses due to mortality of lambs/kids in the Kingdom can be possibly estimated to be around 130,837,500 SR. If all flocks of sheep and goats in the Kingdom were vaccinated against FMD using an average of two doses every year, about 23260,000 sheep doses will be annually required. The estimated price of sheep dose of FMD vaccine is $3 \mathrm{SR}$. Therefore, the annual total price of the required FMD vaccine to vaccinate all the indigenous sheep and goats in the Kingdom may be about $69,780,000 \mathrm{SR}$ with cost benific ratio of $1: 1.875$.

\section{Proposals for control.}

1- Control mreasure based on vaccination and including:

Obligatory standard FMD vaccination regimen applied as below

A) Lambs/kids primary vaccination at the age of 3 months, followed by a booster at four months of age and herd vaccination at 6 months intervals. B) Pregnant ewes, only one vaccine dose at 2 months before lambing. A locall manufaturied vaccine of good quality should facilitate implementing of a nationwide vaccination campaign. In addition, the application of routine FMD vaccination for indigenous sheep and goats will improve the national control of the disease and will make the presently applied control in dairy farms more efficient.

2-Continued monitoring of the relationship between the vaccine and the field viruses will maintain the suitability of the vaccine strains to provide desired protection against the existing field viruses (Kitching et al., 1988., Saumel et al., 1990 a \&b.).

3- Declaring the borders of the country as FMD control areas.

4- Institution of a movement permit system to control all movement of range animals, out of or into the control areas.

5- Prohibition of animal movement to and from the affected Region.

6- Agreements with neighbouring countries in order to ensure that the same standerds of disease control are applied.

7- Emphasis to be placed on the necessity of confirming the efficacy of current animals health measures. 


\section{Assiut Vet. Med. J. Vol. 40 No. 79, October 1998.}

\section{REFERENCES}

AL- Mezaini, S. (1971): "The situation of animal diseases in Saudi Arabia". Bull. Off. int. Epiz. 76, 443-445.

Anderson, E.C., Doughy, W. J. \& Anderson, J. (1976): " The role of sheep and goats on the epizootiology of foot and mouth in Kenya". J. Hyg. Camb. 76, 395-402.

Anon, (1989): Foot and mouth Disease virus antigen detection: ELISA manual. Foot and Mouth Disease-World Reference Laboratory working protocol. $12 \mathrm{pp}$.

Anon, (1996): Agriculture statistical year book, Ministry of Agriculture and Water, Riyadh, Saudi Arabia, 9, 67-70.

Brooksby, J. B. (1981): "Foot- and- mouth disease". In: M.Ristic and I.

Mc Intyre "Disease of cattle in the Tropics: Economic and Zoonotic Relevance", Current Topice in Veterinary Medicine and Animal Science, Martinus Nijholl Publishers, The Hague, 6,pp. 123-132.

Burrows, R. (1968): " The persistance of foot and mouth disease virus in sheep:. J. Hyg. Camb. 66,633-640.

Cottral, G.E.(1969): " Persistance of foot and mouth disease virus in animals, their products and the environement ". Bull. Off. int. Epiz. 71, 549-563.

Dawe, P.S \& Durojaive, O, A. (1986): A preliminary survey of antibody to VIA antigen of foot and mouth disease virus in Nigerian livestock. Rev. sci. tech. Off. int. Epiz., 5(3), 711-714.

Donaldson, A. I. \& Kitching, R. P. (1989): "Transmission of foot and mouth disease by vaccinated cattle following natural challenge". Res. Vet. Sci. 46, 9-14.

Farag, M. A., (1993): Significance of virus infection associated (VIA) antigen as a tool for epizootiological survey to Foot and Mouth Disease in Egypt. Thesis, Cairo University, $71 \mathrm{pp}$.

Fernandez, A. A., DE Mello, P.A., Gomer, I. \& Rosenbero, F.J. (1975): The used of virus infection associated antigen (VIA) in the detection of cattle exposed to FMDV. Bol. Centr. Panam. Fiebre Aftosa, 17/18, 19-22.

Golding, S.M., Hedger,R.S. \& Talbot, P. (1976): Radial immunodiffusion and serum neutralization techniques for the assay of antibodies to swine vesicular disease . Res. Vet. Sci. 20, pp.142- 147 


\section{Assiut Vet. Med. J. Vol. 40 No. 79. October 1998.}

Hafez, S.M. (1987): "The epizootiology of foot and mouth disease in dairy farms in Saudi Arabia". Proceeding of the workshop on Dairy production and Processing in Saudi Arabia. Ryiadh, April 1987, 185-198.

Hafez, S.M., Farag, M. A.\& AL-Sukayran,A. (1994): “ The impact of live animal importation on the epizootiology of foot and mouth disease in Saudi Arabia". Dtsch. tierarztl. Wschr. 101,397-402.

Hafez, S.M., Farag, M. A., Mazloum, K.S.\& AL-Bokmy, A.M. (1993 a): Application of double sandwich enzyme linked immunosorbent assay for the diagnosis of Foot and Mouth disease in Saudi Arabia. Dtsch, Tierarztl. wschr, 100, 103 - 106

Hafez, S.M., Farag, M.A. \& AL-Sukayran, A. (1995): " An outbreak of foot and mouth disease in a sheep production farm in Saudi Arabia". Program and Abstracts: 16th Annual Meeting of the Saudi Biological Society, Riyadh, March 1995. 140.

Hafez, S.M., Farag, M.A. \& AL-Sukayran, A.M. (1993 b): “ Epizootiology of foot and mouth disease in Saudi Arabia:II. " Current status on dairy farms and control measures in operation ". Rev. Sci. Off. Int. Epiz. 12, 817-830.

Hedger,R.S. \& Stubbing, a.G.J. (1971): " The carrier state in foot and mouth disease and the probang test". State Vet. J. 26, 45-50.

Kitching, R.P., Rendle, R. \& Ferris, N.P. (1988): " Rapid correlation between field isolates and vaccine strains of foot and mouth disease virus". Vaccine 6, 403-408.

Mcvicar, J. W. \& Sutmoller, P. (1969): “ The epizootiological importance of foot and mouth disease carriers. I I. The carrier status of cattle exposed to foot and mouth disease following vaccination with an oil adjuvant inactivated virus vaccine“. Arch. ges. Virusforsch. 26,217-224

Mcvicar, J. W. \& Sutmoller, P. (1972): Experimental foot and mouth disease in sheep and goats: An epizootiological model ". Arch. ges. Virusforsch. 38, 85-96.

Mcvicar, J.W. \& Sutmoller, P. (1970): Foot and mouth disease: the agar gel diffusion precipitin test for antibody to virus-infectionassociated (VIA) antigen as a tool fior epizootiological surveys. Am. J. Epidemiol., 92, 273-278.

Mcvicar, J.W. \& Sutmoller, P. (1976): “ Growth of foot -and- mouth disease virus in the upper respiratory tract of non- immunised, 
vaccinated and recoverted cattle after intranasal inoculation". J.Hyg. Cambr. 76, 467-481.

Roeder, P. L. \& LE Blanc Smith, P.M. (1987): Detection and typing of Foot and Mouth Disease virus by enzyme linked immun osorbent assay: a sensitive, rapid and reliable technique for primay diagnosis. Res. Vet. Sci. 43,225-232

Salah, M.N. (1961): " Report to the Government of Saudi Arabia on the control of animal diseases". Food and Agriculture Organisation, Expanded Technical Assistance Programme, Project SAU / ANH, Report No. 1311, 20 pp.

Salt, J. (1992): “ The possible epizootiological role of FMD-carrier animals on Saudi Arabia diary farms". National Workshop on Foot and Mouth Disease in Saudi Arabia, November 1992, Riyadh. 5 pp.

Samuel, A.R., Knowdes, N.J. \& Kitching, R.P. (1990 b): “ preliminary antigenic and molecular analysis of strains of foot and mouth disease virus serotype O isolated from Saudi Arabia in 1988 and 1989 ". Report of the Session of the Reaserch Group of the standing Technical committee of the European commission for the control of Foot and Mouth Disease, Lindholm, Denmark. 139-145.

Samuel, A.R., Ouldridge, E.J., Arrowsmth, A.E.M., Kitching, R.P \& Knoweles, N.J. (1990 a): Antigenic analysis of serotype $\mathrm{O}$ foot and mouth disease virus isolates from the Middle East, 1981 to 1988. Vaccine, 8, 390-396.

Sutmoller, P. \& C.A. Gaggero. (1965): Foot and Mouth Disease carrier. Vet. Res., 77: 968 - 969

Sutmol, P. \& Cottral, G.E. (1967): Improved techniques for the detection of FMDV in carrier cattle. Arch. ges. Virusforsch. 21, 170 177

Woodbury, E.L., Samuel, A.R., Knowles, N.J., Hafez, S.M. \& Kitching, R.P.(1994): Analysis of mixed foot and mouth disease virus infections in Saudi Arabia : Prolonged circulation of an exotic serotype. Epidemiol. Infect., 112,201-211.

Yasin, S.A. (1963): " Report to the Governmant of Saudi Arabia on the Control of animal diseases". Food and Agriculture Organisation, Expanded Technical Assistance Programme, Project SAU / ANH, Report No. 1669, 26 pp. 


\section{Assiut Vet. Med. J. Vol. 40 No. 79. October 1998.}
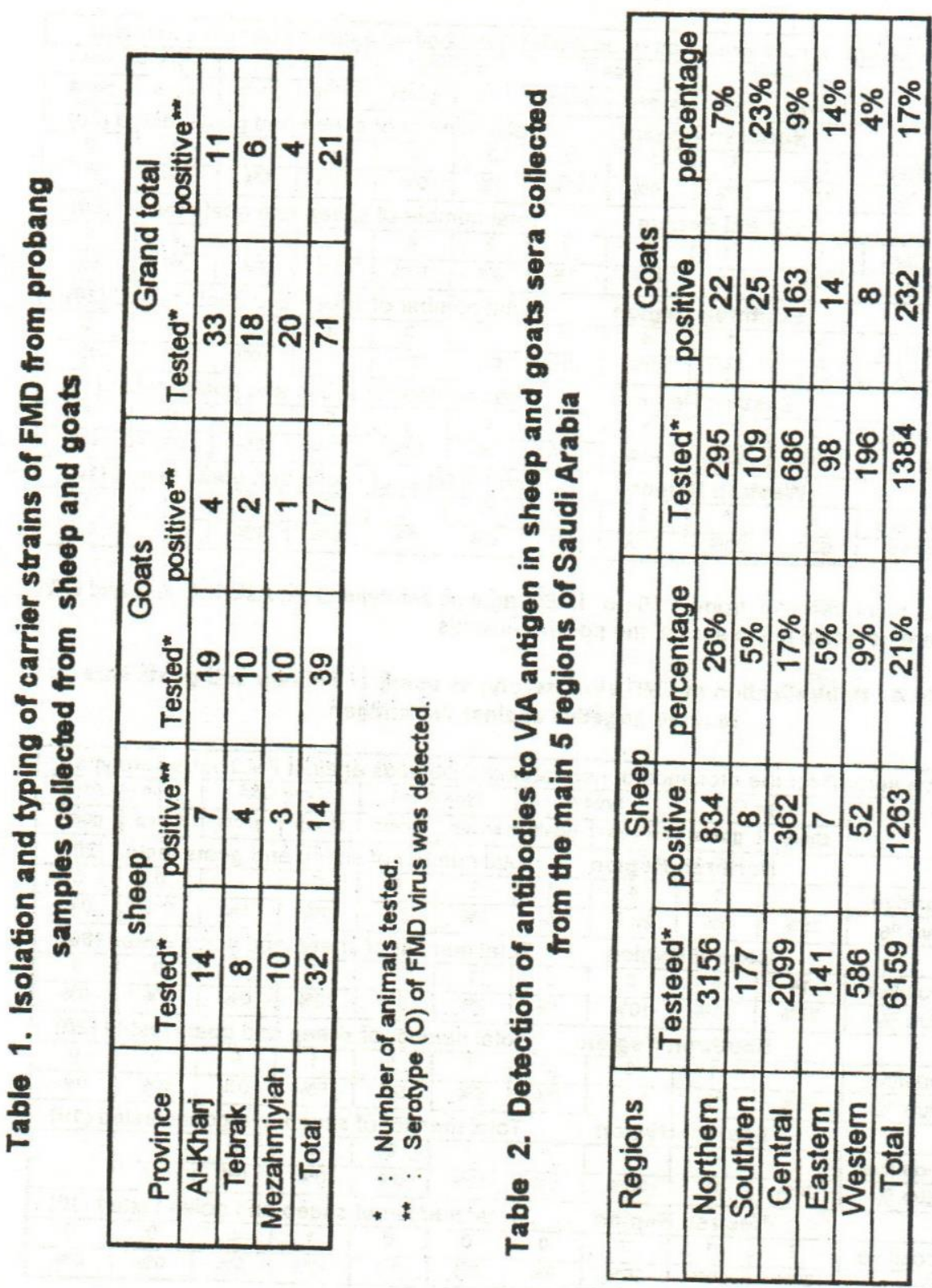

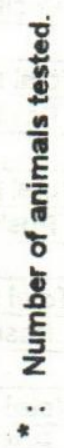


Table 3 . Neutralization of FMD virus serotypes using 150 sheep and goats sera reacted positive against VIA antigen.

\begin{tabular}{|c|c|c|c|c|c|c|c|c|c|c|}
\hline \multicolumn{3}{|c|}{\begin{tabular}{l|l}
\multicolumn{2}{l}{ Positive serum for the prese } \\
\end{tabular}} & \multicolumn{2}{|c|}{ Type A } & \multicolumn{2}{|c|}{ Type Asia 1 } & \multicolumn{2}{|c|}{ Type O\&A } & \multicolumn{2}{|c|}{ Type 08 Asia1 } \\
\hline & sheep & goats & sheep & goats & sheep & goats & sheep & goats & sheep & goats \\
\hline & \multicolumn{4}{|c|}{ Northren Region } & \multicolumn{6}{|c|}{ Total number of sheep and goats tested (30) } \\
\hline Total positive & 12 & 8 & 3 & 3 & 0 & 0 & 4 & 0 & 0 & 0 \\
\hline Positive \% & $40 \%$ & $27 \%$ & $10 \%$ & $10 \%$ & $0 \%$ & $0 \%$ & $13 \%$ & $0 \%$ & $0 \%$ & $0 \%$ \\
\hline \multicolumn{11}{|c|}{ Central Region } \\
\hline Total positive & 37 & 11 & 5 & 2 & 2 & 4 & 9 & 2 & 2 & 8 \\
\hline Positive \% & $46 \%$ & $14 \%$ & $6 \%$ & $3 \%$ & $3 \%$ & $15 \%$ & $11 \%$ & $3 \%$ & $3 \%$ & $8 \%$ \\
\hline \multicolumn{11}{|c|}{ Southren Region } \\
\hline Total positive & 9 & 1 & 4 & 2 & 0 & 0 & 2 & 2 & 0 & 0 \\
\hline Positive \% & $45 \%$ & $5 \%$ & $20 \%$ & $10 \%$ & $0 \%$ & $0 \%$ & $10 \%$ & $10 \%$ & $0 \%$ & $0 \%$ \\
\hline \multicolumn{11}{|c|}{\begin{tabular}{l|l|l|}
$45 \%$ & $5 \%$ & \\
& Eastern Region
\end{tabular}} \\
\hline Total positive & 5 & 3 & 1 & 0 & 0 & 1 & 0 & 0 & 0 & 0 \\
\hline Positive \% & $50 \%$ & $30 \%$ & $10 \%$ & $0 \%$ & $0 \%$ & $10 \%$ & $0 \%$ & $0 \%$ & $0 \%$ & $0 \%$ \\
\hline \multicolumn{11}{|c|}{ Westren Region } \\
\hline Total positive & 6 & 2 & 2 & 0 & 0 & 0 & 0 & 0 & 0 & 0 \\
\hline Positive \% & $60 \%$ & $20 \%$ & $20 \%$ & $0 \%$ & $0 \%$ & $0 \%$ & $0 \%$ & $0 \%$ & $0 \%$ & $0 \%$ \\
\hline
\end{tabular}

* various titers ranging from $1: 10$ to $1: 160$ against serotype $O, A, A s i a 1, O$ \& $A$ and 0 \& Asia1 were detected in the sera of the positive animals.

Table 4. Neutralization of FMD virus serotypes using 120 sheep and goats sera reacted negative against VIA antigen.

\begin{tabular}{|c|c|c|c|c|c|c|c|c|c|c|}
\hline \multirow[t]{2}{*}{ - } & \multicolumn{2}{|c|}{ Type O } & \multicolumn{2}{|c|}{ Type A } & \multicolumn{2}{|c|}{ Type Asia1 } & \multicolumn{2}{|c|}{ Type O\&A } & \multicolumn{2}{|c|}{ Type O\& Asia1 } \\
\hline & sheep & goats & sheep & goats & sheep & goats & sheep & goats & sheep & goats \\
\hline \multicolumn{11}{|c|}{ Northren Region T } \\
\hline Total positive & 5 & 1 & 4 & 1 & 1 & 0 & 0 & 0 & 0 & 0 \\
\hline Positive \% & $25 \%$ & $5 \%$ & $20 \%$ & $5 \%$ & $5 \%$ & $0 \%$ & $0 \%$ & $0 \%$ & $0 \%$ & $0 \%$ \\
\hline \multicolumn{11}{|c|}{ Central Region } \\
\hline Total positive & 14 & 8 & 6 & 2 & 1 & 2 & 7 & 0 & 0 & 0 \\
\hline Positive \% & $23 \%$ & $13 \%$ & $10 \%$ & $3 \%$ & $2 \%$ & $3 \%$ & $12 \%$ & $0 \%$ & $0 \%$ & $0 \%$ \\
\hline \multicolumn{11}{|c|}{ Southren Region } \\
\hline Total positive & 7 & 1 & 3 & 0 & 1 & 1 & 1 & 0 & 0 & 0 \\
\hline Positive \% & $35 \%$ & $5 \%$ & $15 \%$ & $0 \%$ & $5 \%$ & $5 \%$ & $5 \%$ & $0 \%$ & $0 \%$ & $0 \%$ \\
\hline \multicolumn{11}{|c|}{ Eastern Region } \\
\hline Total positive & 2 & 0 & 3 & 0 & 1 & 0 & 0 & 0 & 0 & 0 \\
\hline Positive \% & $20 \%$ & $0 \%$ & $30 \%$ & $0 \%$ & $10 \%$ & $0 \%$ & $0 \%$ & $0 \%$ & $0 \%$ & $0 \%$ \\
\hline \multicolumn{11}{|c|}{ Westren Region } \\
\hline Total positive & 2 & 1 & 2 & 0 & 0 & 0 & 1 & $\overrightarrow{0}$ & 0 & 0 \\
\hline Positive $\%$ & $20 \%$ & $10 \%$ & $20 \%$ & $0 \%$ & $0 \%$ & $0 \%$ & $10 \%$ & $0 \%$ & $0 \%$ & $0 \%$ \\
\hline
\end{tabular}

* various titers ranging from 1:10 to 1:160 against serotype $O, A, A$ sia1 and $O$ \& $A$ were detected in the sera of the positive animals. 


\section{Assiut Vet. Med. J. Vol. 40 No. 79, October 1998.}

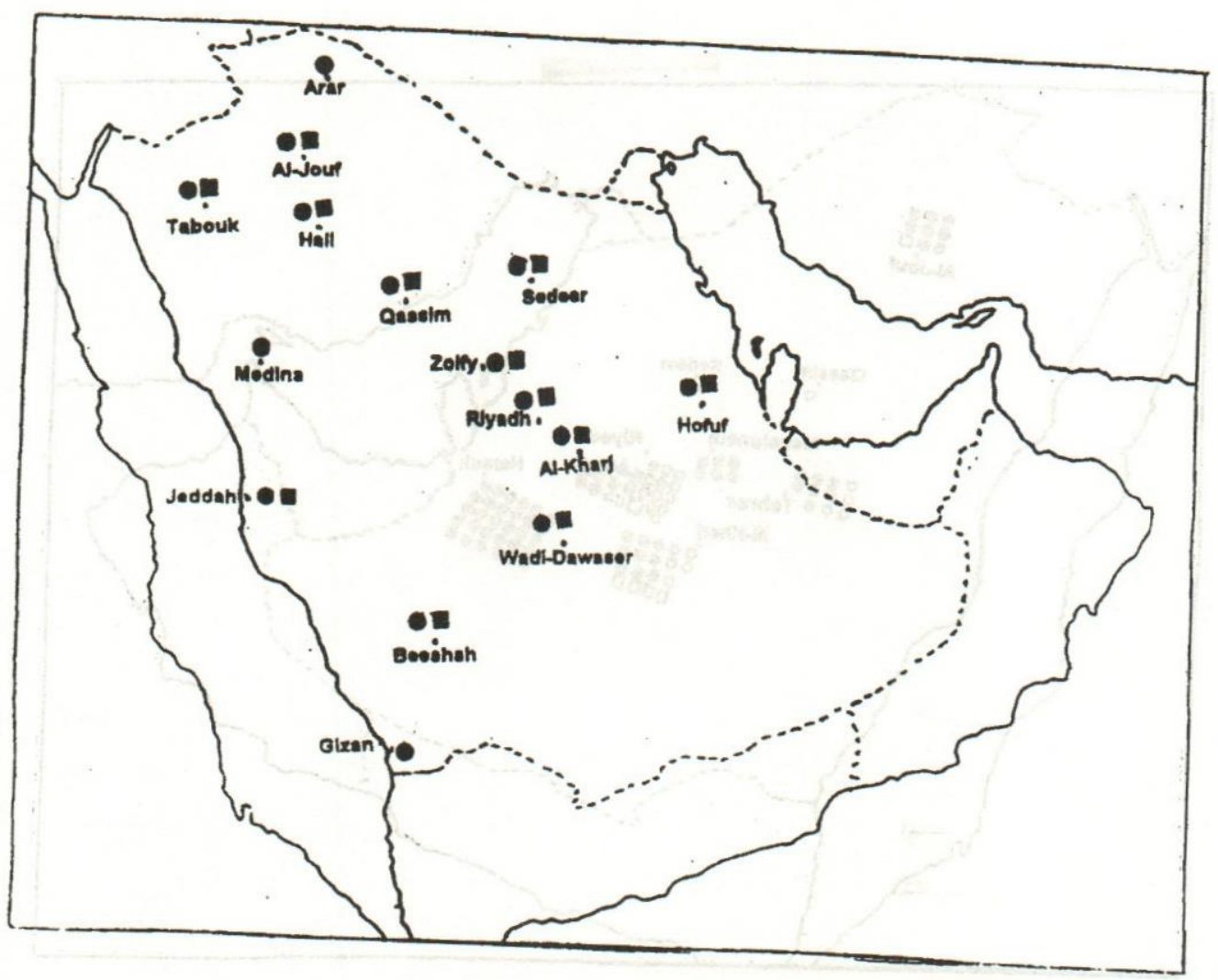

Figure 1.

Map of Saudi Arabia indicating the location of fifteen provinces and the sheep and goats in which precipitating antibodies against virus infection associated antigen were detected 
Assiut Vet. Med. J. Vol. 40 No. 79. October 1998.

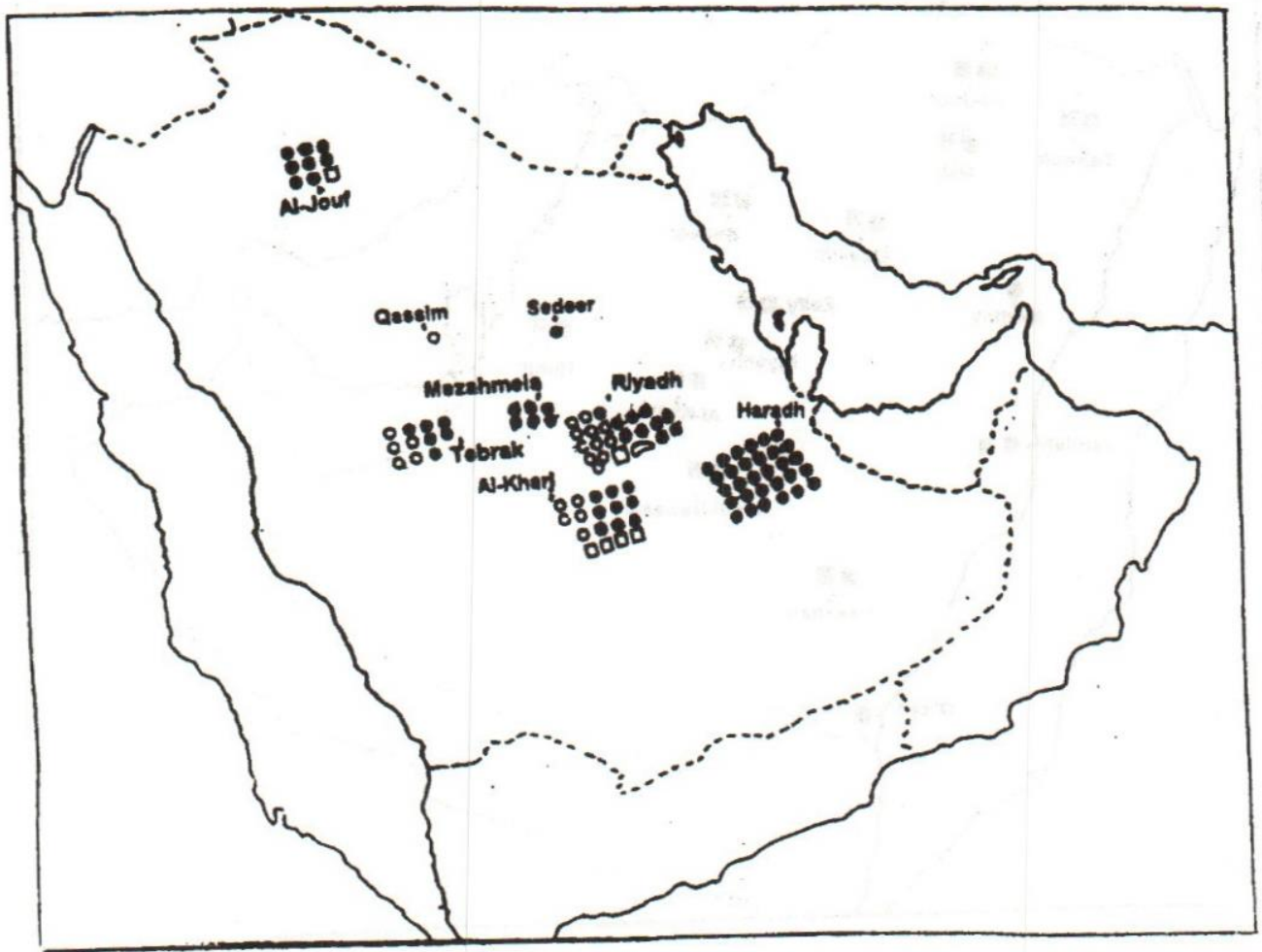

Figure 2.

Map of Saudi Arabia showing the geographical distribution of foot and mouth disease virus serotype $O$, A and Asial isolated from sheep and goats

Type 0 Type A Type Asia1

Sheep

Goats

O

$\infty$ 
Assiut Vet. Med. J. Vol. 40 No. 79, October 1998.

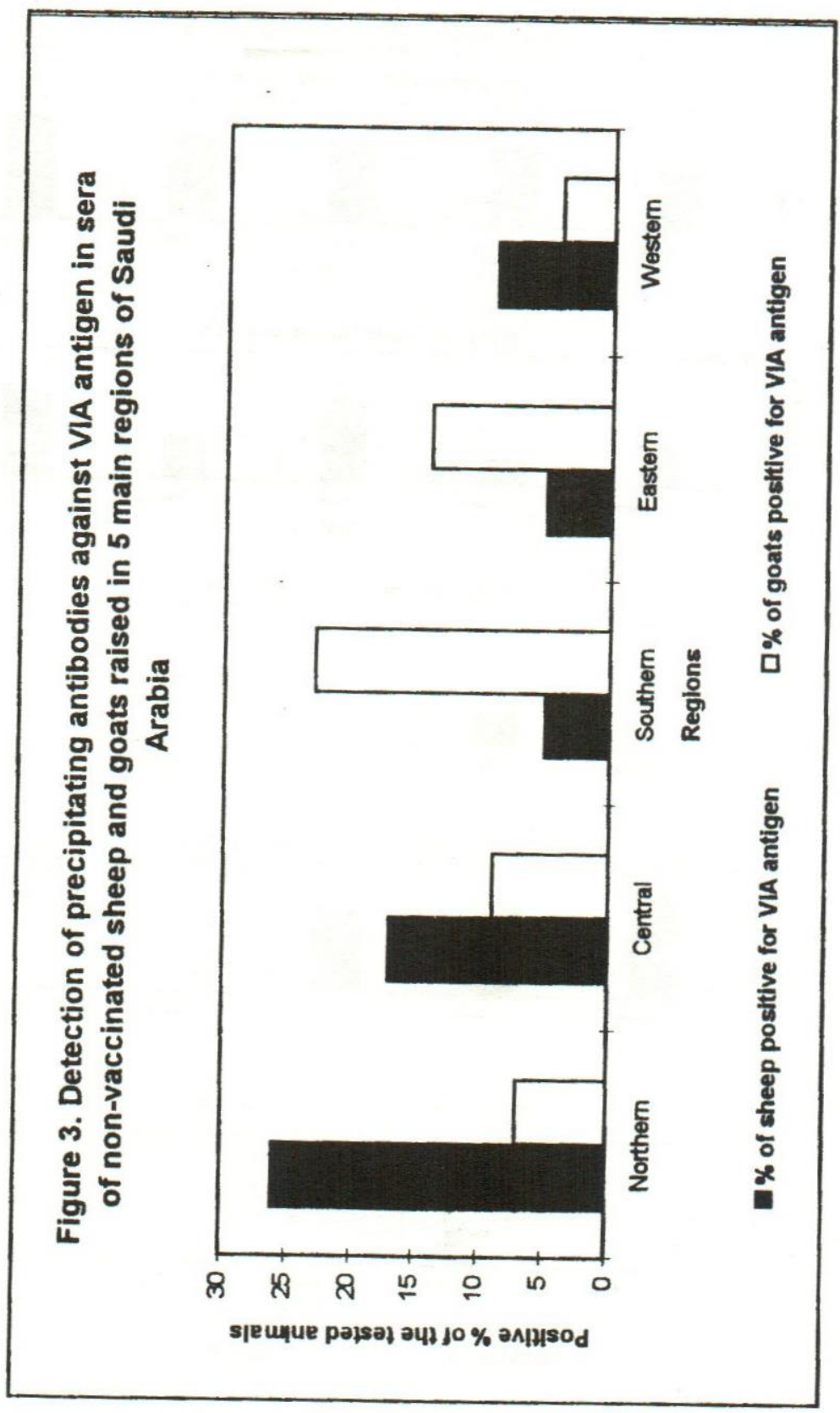


Assiut Vet. Med. J. Vol. 40 No. 79. October 1998.

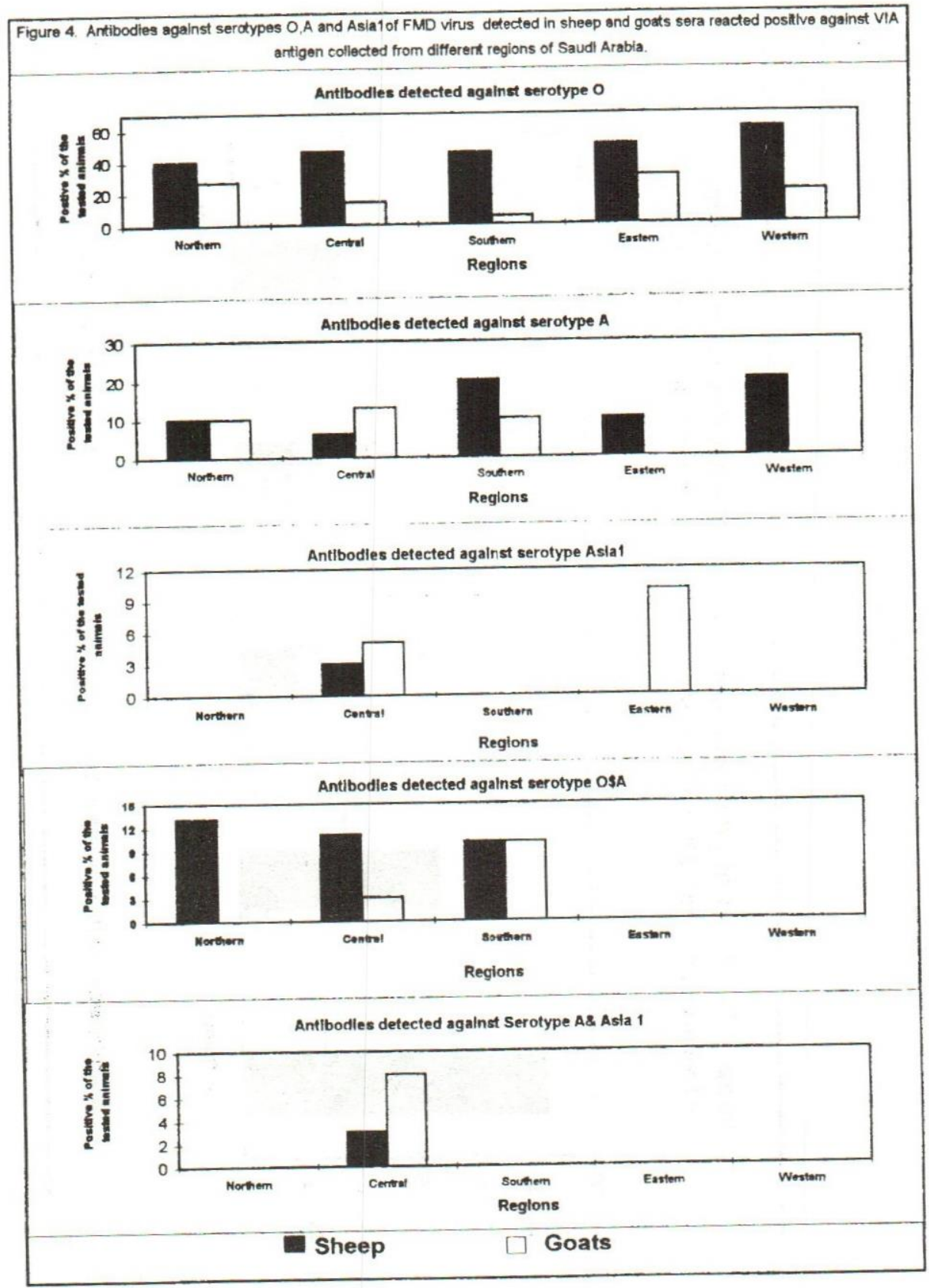




\section{Assiut Vet. Med. J. Vol. 40 No. 79. October 1998.}

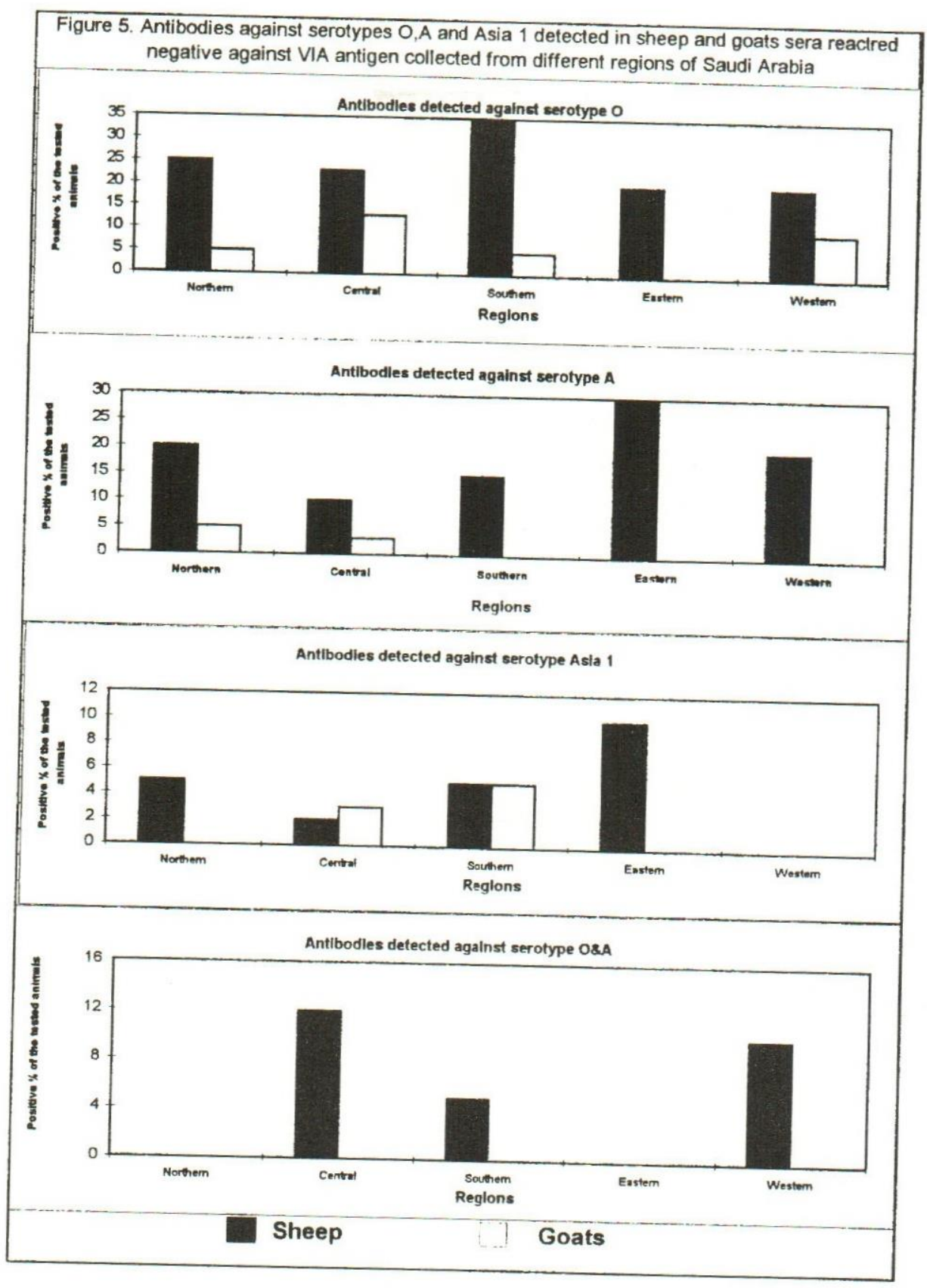


